О. М. Хвисюк, В. Г. Марченко, Ю. А. Коломійченко, Л. А. Страшок, О. Ю. Гончарова, В. В. Жеребкін, М. П. Гиря, Т. О. Кудрявцева Харківська медична академія післядипломної освіти

\title{
ДОСВІД ФОРМУВАННЯ ЛІДЕРСЬКОЇ КОМПЕТЕНТНОСТІ ВИКЛАДАЧІВ ХАРКІВСЬКОЇ МЕДИЧНОЇ АКАДЕМІЇ ПІСЛЯДИПЛОМНОЇ ОСВІТИ
}

\author{
O. M. Khvysiuk, V. H. Marchenko, Yu. A. Kolomiichenko, L. A. Strashok, \\ O. Yu. Honcharova, V. V. Zherebkin, M. P. Hyria, T. O. Kudriavtseva \\ Kharkiv Medical Academy of Postgraduate Education

\section{EXPERIENCE OF FORMATION OF KHARKIV MEDICAL ACADEMY OF POSTGRADUATE EDUCATION TEACHERS' LEADERSHIP COMPETENCY}

\begin{abstract}
У даній статті проведено аналіз наукових праць щодо дослідження лідерської компетентності та професійного рівня викладачів вищих медичних навчальних закладів і висвітлюється досвід формування лідерських здібностей викладачів Харківської медичної академії післядипломної освіти. Доведено, що в умовах інтелектуальної конкуренції безперервне самовдосконалення, педагогічний пошук і використання інноваційних технологій є обов'язковими вимогами, які пред’являються до викладача-лідера. Наведено опис різних підходів із використанням самоконтролю та самооцінки власної діяльності й стимулювання розвитку лідерських якостей особистості викладача.
\end{abstract}

Ключові слова: медична освіта; лідерська компетентність; викладач; професійний рівень.

The scientific works on the study of leadership competence and professional level of teachers at higher medical schools are analyzed in the article; the experience of formation of Kharkiv Medical Academy of Postgraduate Education teachers' leadership skills is described. It is proved that in the conditions of intellectual competition the continuous-improvement, teaching search and use of innovative technologies are mandatory requirements that are made demands on teacher-leader. Different approaches using self-monitoring and self-evaluation of activities and encourage the development of leadership qualities of teacher's personality are described.

Key words: medical education; leadership competency; teacher; professional level.

Вступ. Модернізація сучасної медичної освіти в Україні обумовлює необхідність підвищення якості підготовки медичних кадрів, професійного рівня викладачів, розвитку та підвищення їхньої лідерської компетентності відповідно до вимог, цілей і завдань національної освіти як складової європейського освітнього простору. Важливим чинником підвищення лідерської компетентності викладачів $є$ озброєння їх не тільки педагогічними знаннями та вміннями, а й сукупністю лідерських знань, навичок, умінь, здатностей і професійно важливих якостей, що відображають ступінь їхньої цілеспрямованої активності.

Як відомо, післядипломну освіту медичних кадрів здійснюють фахівці переважно з вищою медичною та фармацевтичною освітою без спеціальної лідерської підготовки. У зв’язку з цим одним із важливих завдань є створення інформаційно-методичного простору в системі післядипломної медичної освіти для розвитку та підвищення лідерської компетентності викладачів.

Як засвідчує аналіз наукових праць, проблема кадрового забезпечення закладів медичної освіти досліджується вченими в таких основних напрямах, як: фундаментальні основи оновлення системи вищої медичної освіти (Л. Артемчук, І. Булах, О. Волосовець, Ю. Вороненко та інші), характеристика професійних якостей викладача вищої школи (А. Деркач, I. Ісаєв, Є. Клімов та інші), обгрунтування необхідності вдосконалення професійної підготовки викладачів вищої школи, теоретичні та методичні засади формування професіоналізму, професійної культури, професійної майстерності (Н. Гузій, О. Дубасенюк та інші),

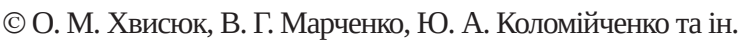


аналіз вмінь, функцій, технологій діяльності викладача (В. Козаков, Л. Мітіна та інші), дослідження феномену професійної компетентності викладача (В. Андрущенко, Л. Кайдалова, В. Лозова та інші). Зауважимо, що окремі аспекти формування лідерської компетентності висвітлено у наукових працях зарубіжних та вітчизняних педагогів і психологів, а саме М. Брауна, Р. Джіннета, М. Мерфі, В. Добриніна, В. Ананьєва, А. Асмолова та ін. У роботі В. Жигарь визначено сутність поняття “лідерська компетентність менеджера освіти” та схарактеризовано їі базові елементи. Проте, незважаючи на значний інтерес науковців до цього питання, проблема формування лідерської компетентності викладачів вищих медичних навчальних закладів, зокрема післядипломних, як у теоретичному, так і в практичному аспекті залишається малодослідженою.

Мета роботи - висвітлення досвіду формування лідерської компетентності викладачів Харківської медичної академії післядипломної освіти.

Основна частина. Аналіз науково-педагогічної літератури свідчить, що дослідники визначають різні аспекти поняття “компетентність”. Так, В. Маслов характеризує компетентність як готовність викладача на професійному рівні виконувати свої посадові та фахові обов'язки відповідно до сучасних теоретичних надбань і кращого досвіду, наближення до світових вимог і стандартів. Відповідно до цього, компетентність $є$ поєднанням науково-теоретичних знань із практичною діяльністю конкретної людини, яке дає змогу постійно забезпечувати високий кінцевий результат [1].

В. Маслов зазначає, що ознаками компетентності $€$ : наявність знань для успішної діяльності; розуміння цих знань для практики; набір операційних умінь, володіння алгоритмами вирішення задач; здатність творчо підходити до професійної діяльності [1].

Щодо тлумачення поняття “лідерство”, то С. Калашникова визначає його як соціально-психологічний феномен, що пов'язаний із динамічними процесами у малій групі та характеризує відношення домінування і підпорядкованості. Дослідниця вважає, що ефективне лідерство сприяє досягненню групових цілей в оптимальні терміни з максимальним ефектом, а лідер є ініціатором та організатором групової діяльності [2].

У наукових працях В. Сибірцева лідерство розглядається як провідне положення особистості, що обумовлене наявністю відповідних якостей, які спричиняють якісну та ефективну діяльність; як процес впливу особистості чи соціального утворення на власну діяльність або діяльність інших на основі особистих якостей [4].

Враховуючи різні погляди науковців, під лідерською компетентністю викладача закладу післядипломної медичної освіти будемо розуміти здатність ефективно здійснювати професійно-педагогічну діяльність, швидко оволодівати інноваційними освітніми технологіями, ефективно застосовувати їх у реальній освітній практиці, при цьому виконувати ролі керівника, організатора, наставника, ментора, супервізора, консультанта, дослідника, доповідача та ін.

Важливою ознакою лідерства більшість науковців вважає лідерський потенціал, що є соціальнопсихологічною властивістю особистості, яка відображує здатність індивіда до успішного здійснення лідерства, як сукупності внутрішніх потреб, засобів, ціннісного ставлення, які сприяють досягненню такого рівня інтеграції компетентності, відповідальності, активності та комунікабельності, що забезпечує провідний вплив на членів групи при спільному вирішенні завдань у різних видах життєдіяльності та задає позитивну спрямованість процесу професійного становлення. Рівень лідерського потенціалу визначається ступенем розвитку його індивідуальної й універсальної складових [3]. Лідерський потенціал особистості з позиції психологічного аналізу має такі складові: комунікабельність, цілеспрямованість, відповідальність, наполегливість, мотивацію до успіху, урівноваженість, розсудливість, позитивну самооцінку, упевненість у собі, щирість, рішучість, розвинуту інтуїцію, чутливість, готовність до ризику (інноваційність), критичність і самокритичність та реалізується через емоційну, поведінкову та когнітивну гнучкість [4].

Ми погоджуємося з думками науковців і вважаємо, що саме ці складові лідерського потенціалу $€$ основою для здійснення викладачем-лікарем успішної освітньої діяльності у закладах післядипломної медичної освіти.

3 метою визначення та розвитку лідерського потенціалу молодих викладачів у ХМАПО організовано “Школу лідерства” (далі - Школа), діяльність якої має сприяти не тільки вдосконаленню майстерності молодих викладачів шляхом оновлення та розширення їхньої професійно-педагогічної компетентності, а й створенню в ХМАПО середовища для професійного розвитку, формуванню лідерської позиції з метою саморозвитку й самовдосконалення, сприяння адаптації у педагогічному середови- 
щі. Школа є однією з форм колективної, групової та індивідуальної роботи, та виконує функції: діагностичну, організаційно-методичну, навчальнопросвітницьку, консультаційну, розвивальну.

Оскільки лідерська компетентність викладачалікаря полягає не лише в якісному виконанні ним своїх посадових обов'язків, але й в особливостях його особистісних якостей, то основними завданням Школи є: формування теоретичних основ ефективного лідерства, стилів ефективного управління, сутності педагогічних конфліктів та способів їх вирішення тощо; набуття вмінь управляти собою, іншими, групою; удосконалення навичок ефективної взаємодії, делегування; вибір оптимального стилю управління та мотиваційних стратегій у роботі зі слухачами й професорсько-викладацьким складом; розвиток здатностей постійно рухатися вперед, приймати рішення в складних ситуаціях; домагатися поставлених завдань; бачити перспективи; співпрацювати; налаштовуватися на зміни; взаємодіяти з носіями інших стилів при прийнятті рішень та їх впровадженні; формувати команду; управляти аудиторією.

Перш за все запорукою успішності професійної діяльності викладачів є удосконалення особистісних якостей: лідерської спрямованості, лідерського потенціалу, харизми, відповідальності, прагнення до успіху, готовності до змін, самовдосконалення та ін. В освіті розвивається тенденція, пов’язана 3 переходом на інший тип навчання - інноваційний, що передбачає орієнтацію людини не на минулий і сучасний досвід, а на далеке майбутнє.

Тому на сучасному етапі реформування медичної освіти без зазначених чинників успішним викладачем-лідером стати неможливо, оскільки сьогодення вимагає від нього не тільки професіоналізму, впевненості в собі, оптимістичного світосприйняття, креативності, а й поєднання вузької спеціалізації $з$ готовністю оволодівати новими формами, методами, прийомами та технологіями навчання, систематичним й послідовним впровадженням у практику оригінальних, новаторських способів, прийомів педагогічних дій і засобів, що охоплюють цілісний навчальний процес від визначення його мети до очікуваних результатів.

Наприклад, викладачі-лікарі ХМАПО з лідерськими здібностями успішно використовують інноваційні методики, такі, як електронні підручники, дистанційні системи навчання, наскрізна програма підготовки лікарів-інтернів, майстер-класи, бінарні лекції, “віртуальні пацієнти” тощо. Технологія “віртуальних пацієнтів” набуває актуальності не тільки за кордоном, а і в Україні, коли не можна удосконалювати лікарську майстерність на живих пацієнтах, і дана проблема вирішується за допомогою автоматизованих систем. Для впровадження даних технологій у ХМАПО було: розроблено контент (прямолінійні чи розгалужені кейси) для використання їх у навчальному процесі; створено методичний супровід для викладачів та розробників; написано методичні рекомендації для слухачів; налаштований сервер віртуальних пацієнтів на базі Open Labirinth, який дає додаткові можливості та інструменти для проведення навчального процесу, а саме використання прямолінійних та розгалужених кейсів для роботи із слухачами в режимі дистанційного навчання.

Для визначення динаміки значущих результатів самоосвіти, забезпечення моніторингу професійного зростання, демонстрації здатності до практичного застосування психолого-педагогічних знань у ХМАПО запроваджено створення портфоліо науково-педагогічного працівника.

Портфоліо забезпечує накопичення інформації, необхідної для об’єктивного оцінювання професійно-педагогічної діяльності; відзначення, представлення до нагород за підсумками діяльності. Це дозволяє враховувати результати, досягнуті науково-педагогічним працівником у різних напрямах його професійно-педагогічної діяльності: навчальній, навчально-методичній, науково-дослідній, організаційно-методичній, лікувальній, виховній, самоосвітній.

3 метою підвищення мотивації, ефективності та результативності професійно-педагогічної діяльності; забезпечення прозорості та об’єктивності оцінювання діяльності кожного науково-педагогічного працівника; стимулювання інноваційних видів діяльності, спрямованих на підвищення якості освіти та на встановлення відповідності показників роботи ХМАПО ліцензійним вимогам, деякими кафедрами академії запроваджено рейтингове оцінювання діяльності науково-педагогічного працівника, де основним завданням є: розроблення і використання єдиних комплексних критеріїв для оцінювання ефективності діяльності науково-педагогічних працівників; вдосконалення діяльності через об’єктивний аналіз результативності власної праці; вдосконалення науково-методичної основи викладацької діяльності; виявлення недоліків і проблемних питань у діяльності науково-педагогічних працівників. Такий підхід зумовлює самоконтроль та самооцінку 
власної діяльності і стимулює розвиток лідерських якостей особистості викладача.

Відомо, що педагогічна діяльність викладачів спеціальних медичних дисциплін має деякі особливості, які залежать від освітньо-вікової специфіки тих, хто навчається. Отже, компетентне вирішення професійних завдань вимагає від них постійного підвищення не тільки професійно-педагогічної компетентності, а й лідерської.

Низкою авторів (І. Дичківська, В. Сибірцев та інші) визначено основні методологічні вимоги до будь-якої педагогічної технології, такі, як: концептуальність, системність, можливість управління, ефективність, відтворюваність, візуалізація [4]. Однією з головних вимог інноваційного освітнього процесу у вищому навчальному закладі, у тому числі в ХМАПО, є орієнтація на самостійну діяльність щодо здобуття знань. Тобто лідерська компетентність викладачів як менеджерів іннова-

\section{Список літератури}

1. Маслов В. І. Принципи менеджменту в установах освіти / В. І. Маслов // Освіта і управління. - 1997. № 1. - С. 77-81.

2. Калашникова С. А. Теоретико-методологічні засади професійної підготовки управлінців-лідерів в умовах сучасних суспільних трансформацій : дис. доктора пед. наук : 13.00.06 / С. А. Калашникова. - К., 2011. - 462 с.

3. Міляєва В. Р. Змістовно-структурна модель психологічного забезпечення системи підвищення кваліфі-

\section{References}

1. Maslov, V.I. (1997). Pryntsypy menedzhmentu v ustanovakh osvity [Management principles at educational institutions]. Osvita i upravlinnia - Education and management, 1, 77-81 [in Ukrainian].

2. Kalashnikova, S.A. (2011). Teoretyko-metodolohichni zasady profesiinoi pidhotovky upravlintsiv-lideriv $\mathrm{v}$ umovakh suchasnykh suspilnykh transformatsii : dys.... doctora ped. nauk : 13.00 .06 [Theoretical and methodological basis of professional training of managers under the conditions of modern social transformation : diss....Doctor of Educational Sciences : 13.00.06]. Kyiv [in Ukrainian].

3. Miliaieva, V.R. (2011). Zmistovno-strukturna model psykholohichnoho zabezpechennia systemy pidvyshchennia kvalifikatsii derzhavnykh sluzhbovtsiv [Conceptual and ційного освітнього процесу проявляється у готовності опанувати сучасні інформаційні технології та використовувати їх навчально-виховний потенціал у своїй роботі з метою формування у слухачів аналітичних, інформаційних, пізнавальних і проективних умінь.

Висновки. Отже, досвід формування лідерської компетентності викладачів ХМАПО має свої особливості, що зумовлені специфікою навчання дорослих людей з вищою освітою, досвідом лікарської й педагогічної діяльності, існуванням багаторівневої моделі підвищення кваліфікації фахівців, варіативністю застосування технологій.

Проведені дослідження спрямовані на пошук та реалізацію шляхів, методів і засобів удосконалення лідерської компетентності викладачів, що дозволить у подальшому моделювати професійну діяльність, кар’єру і соціально значимі цінності викладачів закладів післядипломної медичної освіти.

кації державних службовців / В. Р. Міляєва // Науковий вісник Південноукраїнського національного педагогічного університету ім. К. Д. Ушинського : зб. наук. праць. - Одеса : ПНПУ ім. К. Д. Ушинського, 2011. - № 11-12. - C. 137-144.

4. Сибірцев В. Професійна компетентність учасників інноваційного навчально-виховного процесу у вищому навчальному закладі / В. Сибірцев // Теорія та методика управління освітою. - 2010. - № 3. - С. 1-10.

structural model of psychological providing career development system of government employees] Naukovyi visnyk Pivdennoukrainskoho natsionalnoho pedahohichnoho universutetu im. Ushynskoho - "Scientific newsletter" of South Ukrainian National Pedagogical University named after K. D. Ushynsky, 11-12, 137-144 [in Ukrainian].

4. Sybirtsev, V. (2010). Profesiina kompetentnist uchasnykiv innovatsiinoho navchalno-vyhovnoho protsesu u vyshchomu navchalnomu zakladi [Professional competency of participants of innovative teaching and educational process at higher educational institution]. Teoria ta metodyka upravlinnia osvitoiu - Theory and methods of educational management, 3, 1-10 [in Ukrainian].

Отримано 24.03.17 